\title{
17 Managing Stakeholders Conflicts
}

\author{
Helder Moura and José Cardoso Teixeira
}

\subsection{Conflicts: a behavioural process}

It is not unusual that a chapter on conflict management, which is about, generally speaking, helping people or organizations that are in conflict with each other to deal with their differences, opens up with this statement (Moore, 1986 cited in Gordon, 1966):

All societies, communities, organizations, and interpersonal relationships experience conflict at one time or another in the process of day-to-day interaction. Conflict is not necessarily bad, abnormal, or dysfunctional; it is a fact of life.

Typically, a conflict situation results from resource shortage and antagonistic feeling. Conflicts may arise between individuals, between groups of individuals and between organizations. Conflict situations between people are subjective, meaning that although objective reasons may exist, conflict only breaks out if those reasons are perceived. Conflicts between people may trigger out organizational conflicts for the simple reason that organizations are (still) governed by people. However, organizational conflicts may have other root reasons, for example resource interdependency. A common definition of conflict is a process that begins whenever an individual or a group feels negatively affected by another individual or group. In other words, people are in conflict anytime one's actions obstruct or by any means, make other's performance, less efficient.

Individual conflicts exist in all human relations and those within the construction activity are no exception. Due to the great diversity of people involved in construction projects and to the enormous variety of situations emerging from the construction process, individual conflicts in this activity deserve particular attention. Groton (1997) found that conflicts between people in construction arise as a result of poor interpersonal skills, inefficient communication, lack of responsiveness and unethical or opportunist behaviour. Conflicts of this nature may remain within the individual sphere of people involved or build up to the organizations they work for if not adequately handled. This may easily develop into organizational conflicts, affecting several organizations participating in a construction project.

On the other hand, because organizations act through individuals, then conflict events emanate from key actors within the organizations, due to their different perceptions on a particular aspect about which they are unable to agree. This applies both to group conflicts within an organization (for example, inter-department conflicts within a contractor's organization) and to conflicts affecting several organizations working together in a construction project (for example, between the owner and the contractor). Beyond people issues mentioned above, Groton (1997) suggested two main identifiable group causes for organization conflicts: project uncertainty and process problems. Examples of the former 
are pre-existing conditions and outside forces and of the latter are incomplete project scope definition and poor performance.

In view of the above, the following definition for a conflict applies: an interaction of independent people who acknowledge different objectives, wishes and values in the other part, capable of interfering with their own. In this statement, there are three ingredients that seem to be present in every conflict: interdependence, perception (at least by one part) and antagonism.

In fact, conflict has always been present in organizations taking part in construction ventures since ancient times. One of the first reported conflict management practice between construction stakeholders took place in Ancient Greece (some authors identify the first civil engineer in European history as the Greek Eupalinos, responsible for the construction of the Samos island tunnel in the year $550 \mathrm{BC}$ ), where, after public interviews for selecting the contractor of a new statue or building, citizens were informed about actual progress and the cost of the construction project. This and other type of measures related to conflict avoidance tactics were also used in Ancient Rome, where construction contracts ought to define technical specifications, materials, guarantees or payment schedules, in order to adequately distribute risk between the owner and the contractor. Moreover, some conflicts have so deep historical, cultural and political roots that they are seeded by unstructured discernment and cannot be managed by the traditional way (for instance, the resolution of stakeholders' conflicts resulting from construction errors were already a concern in the ancient Hammurabi Code of Laws dated back to about the 18th century вс).

The first perception is that a conflict in construction has negative consequences but it may not be the case. Literature generally distinguishes between functional and dysfunctional conflicts. A functional conflict leads to the improvement of the production process or to a better outcome than would otherwise be expected. On the other hand, a dysfunctional conflict prevents progress, has negative effects in production and conducts to poor outcomes. The former is positive or productive while the latter is destructive and generally leads to disputes. Additionally, a functional conflict may lead to or degenerate into a dysfunctional conflict if inadequately managed.

Generally speaking, construction stakeholders aim at preventing disputes because of their possible harsh consequences. Some people will fiercely try to avoid conflicts because of the fear that conflict escalation will lead to unpredictable effects or retaliation. But there are also people who may benefit from disputes in terms of financial advantages, identity, status or power. For those people, a dispute may be viewed as an opportunity to engage diverse opinions and ideas from people holding different perspectives on the conflict issue.

The best way for solving conflicts (either individual or institutional) is transforming them into problems - or preventing them to evolve from these. The fundamental difference between these two concepts is that unlike in conflicts, there is no negative attitude or even hostility between parties involved in problems. In a conflict, there are antagonistic parties whereas in a problem there is a set of people working together to reach a solution. For problem solving, it is paramount that each individual feels he or she is part of the solution, not part of the problem.

The first step for conflict solving is conflict analysis, encompassing conflict types and conflict causes. Although these have broadly been addressed above, root causes for conflicts must be further investigated. Additionally, as with any other social course of action, there is a conflict process bringing in results and effects. The following sections present the most common types of conflicts between construction stakeholders and explain how they can be effectively managed. 


\subsection{Types of conflicts in the construction activity}

Conflicts vary in terms of their legal, political and institutional framework, economic constrains and pressures, people's culture, social structure, stakeholder interests, technical knowledge, environment and history just to name a few influencing factors.

Conflicts may involve stakeholders external or internal to the project or a combination of those. Conflicts between external stakeholders may be the most difficult to resolve because of their diversity and because of the lack of established procedures for tackling most of them. For example, in developed societies, public opinion tends to be more opponent than supporter of a construction project encompassing some environmental impact, although it may respond to a specified public need; on the contrary, in less developed or poorer countries, public may be more keen to accept the project if it aims at solving important infrastructure needs (transportation, sewage, pipelines, water treatment, etc.).

Conflicts may involve two parties or several parties for the same reason or for a diversity of reasons. For example, a construction project may trigger out conflicts between the contractor and the client for lack of quality and excessive cost of the output, between the public administration and both the promoter and the contractor for noise impact and between the contractor and the site neighbours for lack of parking places on the surrounding area. The first step for adequately managing those conflicts is looking at them one by one. Still, a specific conflict may involve several parties from each side. Figure 17.1 shows the conflict logics between a set of $\mathrm{m}$ parties (individuals, institutions, etc.) from one side and a set of $n$ opponents from the other side split into $m \times n$ conflicts between each pair of parties.

In the following subsections, it is assumed that conflicts involving several parties may always be broken up in a set of conflicts between two parties taking place at the same time.

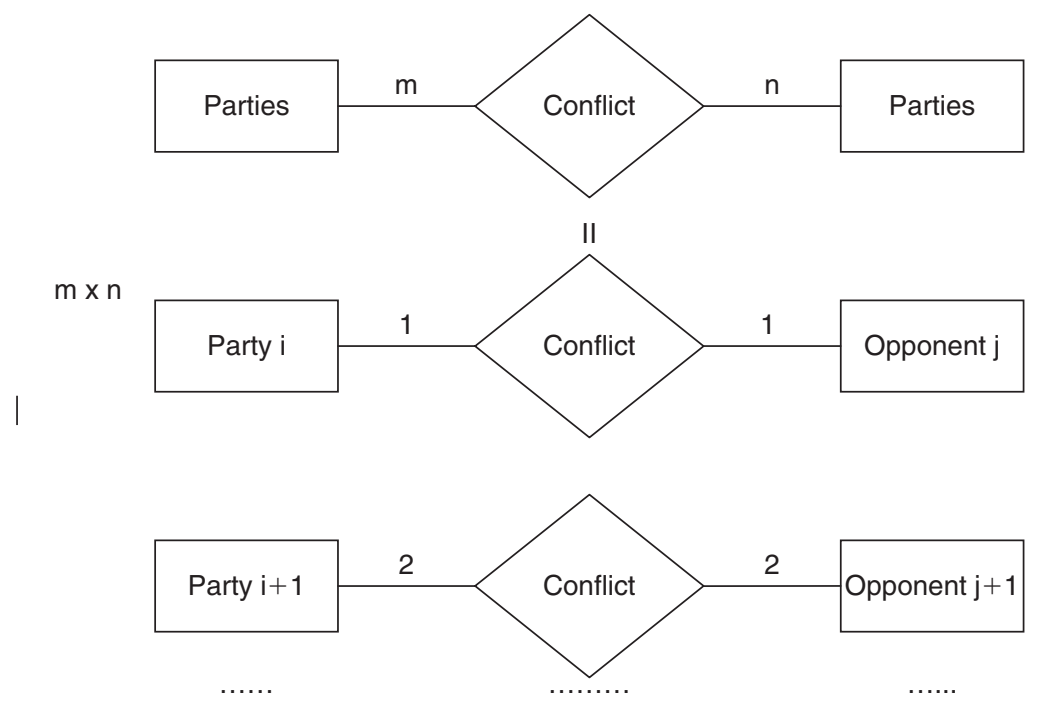

Figure 17.1 Splitting conflicts among several parties into a set of conflicts between two parties. 
Conflicts may also be categorized in respect of the typology in:

- Open conflicts, when it is everyone's knowledge.

- Hidden conflicts, when it is known of some people only.

- Latent conflicts, when the conflict comes to the surface if, and only if, something changes the status quo.

With respect to the clearness of possible solutions, conflicts can be defined as (Rijsberman, 1999):

- Well defined, if they have sharp boundaries and the constraints are well defined; typically, clear solutions to the problem exist.

- Fuzzy or ill defined, if they have unclear objectives, important variables are not quantifiable and the values held by the parties may not be clearly defined. As a result, it may be very difficult to identify feasible solutions.

Actually, conflicts may have facets of both well- and ill-defined problems. In broad terms, well-defined conflicts can be viewed as a subset of ill-defined conflicts. The following subsections point out some solving strategies applicable to different conflict types.

\subsubsection{Conflict level}

The huge diversity of construction conflicts has propelled classification efforts from several authors. One of the simplest classification system found in the literature is by level of occurrence (Gordon, 1996) distinguishing intra-personal conflicts (within the individual), inter-personal (between individuals), intra-grouping (conflict deflates in a restricted group), intra-organizational (within an organization), inter-group (between different groups) and inter-organizational (between organizations).

Intra-personal conflicts obviously exist within construction project teams and construction stakeholders' organizations, as it happens in any organization, because there are people involved. These problems aim to be solved through psychology and are not dealt with in this book.

This chapter focuses on inter-group and inter-organizational conflicts because construction stakeholders (media, authorities, contractors) normally act either as organizations or as groups of individuals with the same interests (users, land owners, nearby residents). Moreover, inter-personal conflicts may lead to conflicts involving several groups and organizations, therefore deserving attention.

Finally, this chapter will not deal with conflicts taking place within construction stakeholder groups and organizations unless they are construction specific. If this is not the case, current approaches for conflict settlement apply and are not treated here. However, intragroup and intra-organizational conflicts may lead to conflicts involving several groups and organizations therefore deserving attention as well.

\subsubsection{Conflict causes}

Inter-personal conflict causes are diverse. Generally speaking, subjective causes for conflicts exist when someone recognizes interference on his or her individual sphere. The individual sphere is a set of tangible and intangible values which we claim the right to detain. Examples of the former are capital assets, property issues like cars or houses and examples of the latter are safety, comfort, pride, time or recognition from the others. 
Published literature on the topic seems to agree on four main causes for inter-group and inter-organizational conflicts:

- Cognitive conflicts, resulting from different evaluation of empirical data or facts, given that parties interpret, combine or deduce different conclusions from the same basic elements. In most cases, it may be realized that data available is insufficient or facts not clear enough to properly assess a situation. This can be resolved by the technical team through additional studies to clarify facts or to obtain additional and more reliable data. And this may contribute for changing the conflict situation into a structured problem.

- Conflicts of objectives or interests, applicable to sharing benefits, rejecting negative consequences of something, financing external costs or allocating disposable resources. These conflicts ought to be solved through sound conflict management techniques.

- Normative conflicts, resulting from divergences about values, behaviours and norms that should prevail in socially adequate conducts. Root causes for these conflicts are ethical and moral principles that are not negotiable. The best approach to this situation is by reformulating the conflicting issue in order to transform it in a conflict of interests.

- Conflicts of relationships are caused by personality or behaviour of stakeholders' representatives. These can normally be solved either by negotiation or, when the conflict has raised over, through mediation by an independent third party.

A more restrictive taxonomy of conflict causes includes conflicts of objectives or interests into cognitive conflicts and merges normative conflicts and conflicts of relationships into a single cause class:

- Cognitive conflicts, normally task-oriented and focused on differences of judgement about data or facts and on the way to achieve objectives.

- Affective or socio-emotive conflicts relating to personality differences, irritability, frictions and animosity, and tend to be more dysfunctional and less constructive.

\subsubsection{Conflict object}

Another way of differentiating conflicts is by object, or basic core (prime matter) of the dispute. Accordingly, the following apply to inter-group and inter-organizational conflicts:

- Conflicts over objectives, needs or interests, when one party perceives that its needs, concerns or objectives are incompatible with the other party's.

- Conflicts over processes arise when people, groups, organizations or institutions use different approaches for solving the same problems.

- Structural conflicts occur due to the way society is structured in terms of social, legal, economical and cultural arrangements, and the relative position and power of each stakeholder within that social order.

\subsubsection{Conflict life cycle}

In a construction project, conflicts may occur in one stage and evolve to the next. In fact, a conflict is a dynamic phenomenon with a specific life cycle, like any construction product. According to some authors (Groton, 1997), there are generally four stages in every conflict: first, conflict progresses from initiation to escalation, then to controlled maintenance, abatement and finally to termination/resolution (Figure 17.2). 


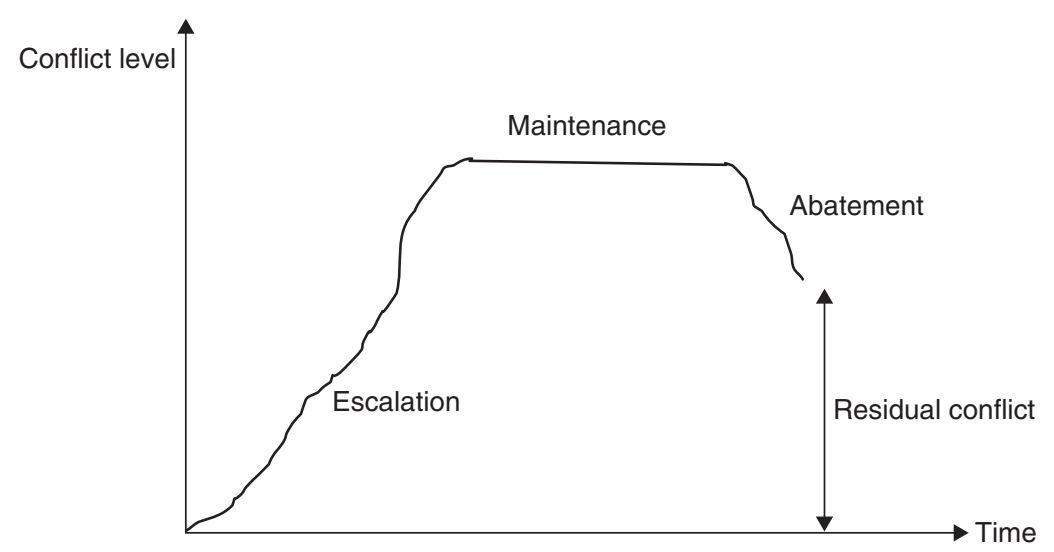

Figure 17.2 Conflict life cycle.

(Source: Adapted from Groton, 1997)

For each one of these stages, there is an appropriate management approach:

- Potential or dormant conflicts: develop power matrix and incorporate needs/interests.

- Erupting conflict, with positions being developed: range the options, depending on the conflict nature and the relationships among parties.

- Evolving conflict:

- $\quad$ Towards litigation: use third party assistance (mediation or arbitration).

- $\quad$ Towards resolution/abatement: no assistance or facilitation may be needed.

- Resolved conflicts: depends on the situation.

Because construction is an interactive process involving several people, with different needs and perceptions during a long time, it is plausible that all types of conflicts may occur. This justifies the need for an adequate management approach for dealing with conflicts in construction. Table 17.1 summarizes the conflict classification described above.

\subsection{Construction stakeholders and potential conflicts}

Project stakeholders are persons, groups or organizations having any interest in the project and who may influence the project planning, design, implementation and future use. Although all projects have its set of different stakeholders, some common classification of stakeholders may be established:

- Key stakeholders like the project owner, suppliers, performing organizations, the project management team and others depending on the project.

- Internal stakeholders, directly participating in the project.

- External stakeholders comprehending people affected by the project, interested parties and statutory authorities.

According to Olander (2003), the stakeholders depicted in Figure 17.3 may be found in a construction project.

Identifying potential conflicts between project stakeholders is an important step towards conflict anticipation and conflict management. Therefore, once project stakeholders are 
Table 17.1 Classification of conflicts

\begin{tabular}{|c|c|c|c|c|c|c|c|c|c|c|}
\hline \multicolumn{4}{|c|}{$\begin{array}{c}\text { Type } \\
\text { Well defined } \\
\text { Fuzzy }\end{array}$} & \multicolumn{2}{|r|}{ Level } & & & & & \\
\hline \multirow{6}{*}{$\begin{array}{l}\text { 증 } \\
\frac{0}{\circ} \\
\text { 물 }\end{array}$} & \multirow{6}{*}{$\begin{array}{l}\text { Фे } \\
\text { Оิ }\end{array}$} & \multirow{6}{*}{$\begin{array}{l}\frac{c}{\bar{d}} \\
\frac{\overline{0}}{\bar{O}} \\
\frac{1}{1}\end{array}$} & \multirow{6}{*}{ 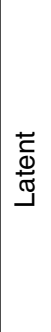 } & \multirow{3}{*}{ 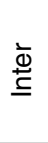 } & Personal & & & & & \\
\hline & & & & & Group & & & & & \\
\hline & & & & & Organization & & & & & \\
\hline & & & & \multirow{3}{*}{ 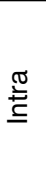 } & Personal & \multirow{3}{*}{ 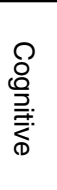 } & \multirow{3}{*}{ 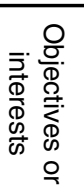 } & \multirow{3}{*}{ 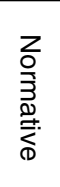 } & \multirow{3}{*}{ 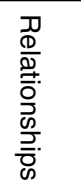 } & \multirow{4}{*}{ 尽 } \\
\hline & & & & & Group & & & & & \\
\hline & & & & & Organization & & & & & \\
\hline & & & & & & \multicolumn{2}{|c|}{ Cognitive } & \multicolumn{2}{|c|}{ Socio-emotive } & \\
\hline & & & & & & \multicolumn{5}{|c|}{ Object } \\
\hline & & & & & & \multicolumn{5}{|c|}{ Objectives, needs or interests } \\
\hline & & & & & & \multicolumn{5}{|c|}{ Processes } \\
\hline & & & & & & \multicolumn{5}{|c|}{ Structural } \\
\hline
\end{tabular}

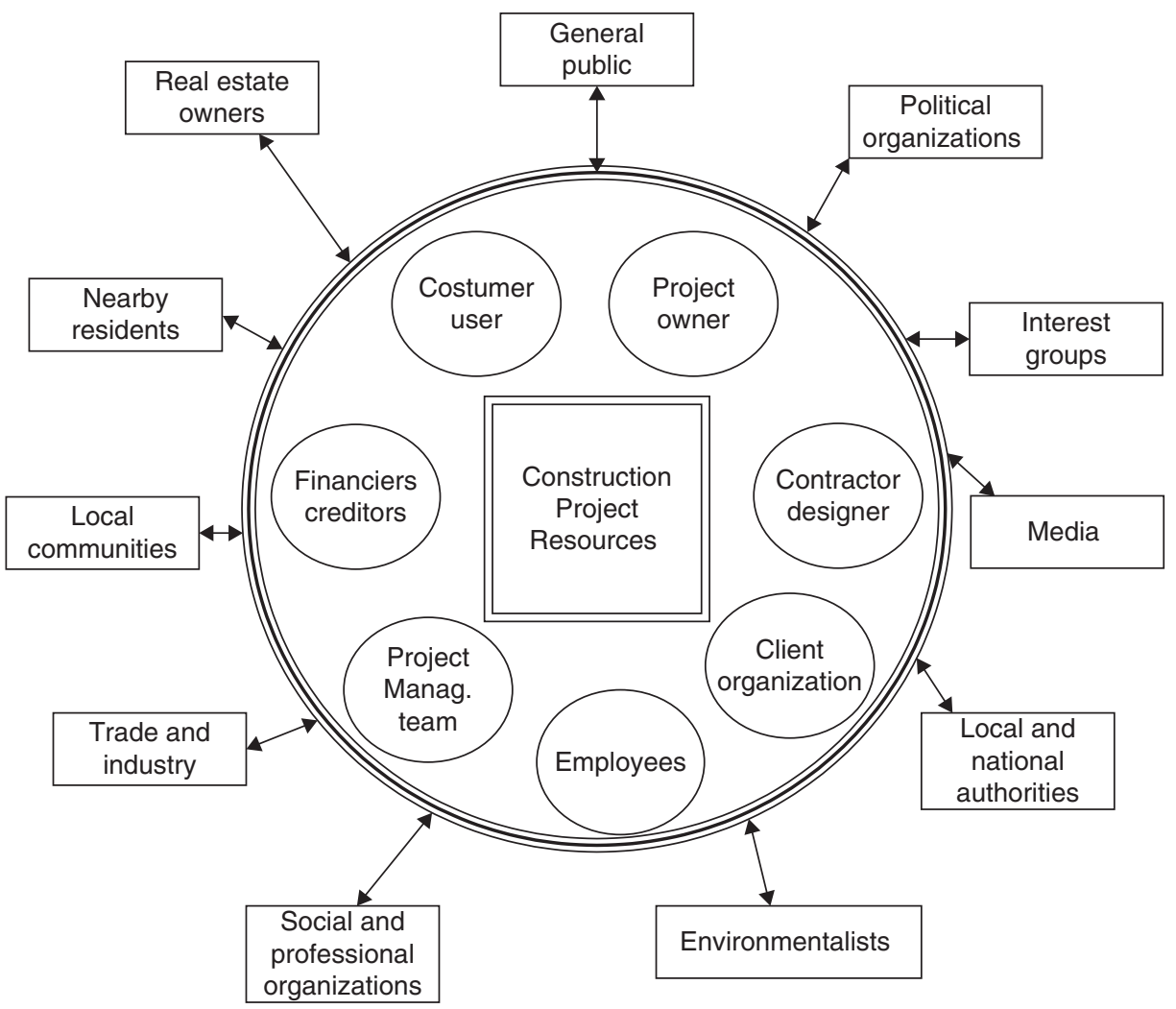

Figure 17.3 Construction project stakeholders.

(Source: Adapted from Olander, 2003) 


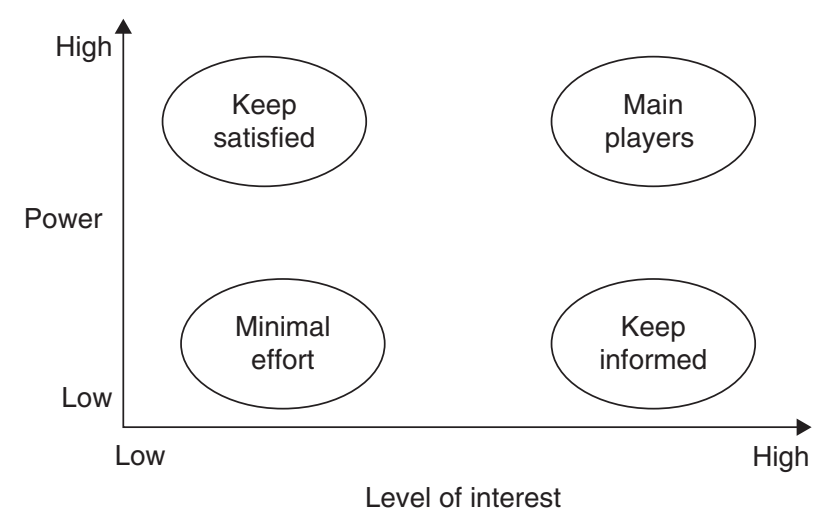

Figure 17.4 Power/interest matrix.

(Source: Adapted from Johnson and Scholes, 1999)

recognized, the next stage is to assess their needs and expectations in relation to the project and the conflicts each stakeholder may possibly become involved in. This depends on:

- the stakeholder (power/interest);

- the type of project (public/private, building/road/industrial);

- the stage of the construction process (design/implementation/use).

\subsubsection{Stakeholder power}

Solving conflicting interests between stakeholders must take into account their relative influence on the implementation of the project. Mapping the power and the interest of stakeholders is an interesting technique for this purpose. Figure 17.4 shows the power/interest matrix (Johnson and Scholes, 1999), which aims to answer the following questions:

- How interested is each stakeholder on the project decisions?

- Are they willing to interfere?

- Do they have enough power to act?

\subsubsection{Key stakeholders}

Key stakeholders are the main players in the project, holding high power to influence the project and high level of interest in it. Main players are more likely than any other stakeholders to create difficulties in solving conflicts if their needs are not attended. Keepinformed stakeholders have great interest in the project (land owners, nearby residents, public in general, groups of interests, environmental bodies) and may be severe opponents to it but have limited power to influence project decisions. Keep-satisfied stakeholders, on the contrary, hold high power to influence the project decisions (investors, authorities, legislative bodies, investors, media), but are often passive, meaning that conflicts with them may be avoided if they feel happy with the implementation of the project. The last set of stakeholders is the minimal effort group, who have low interest in the project, therefore raising few conflicts, and are not able to have a great impact on the decisions (trade and industry, for instance). It is worth noting however that the examples given above between brackets correspond to typical stakeholder positions in mainstream construction projects 
but they may assume other positions sometimes. For example, an environmental body may easily become a key player in a sensitive project.

\subsubsection{Conflicts between external stakeholders}

\section{Real estate owners}

These are people affected by land acquisition for implementing the project. The intensity of conflicts involving real estate owners depends on whether the project is private or public, and if it is implemented in an urban area or in a rural area.

In a private project, real estate owners may be normally included in the 'keep satisfied' group, because the development of the project depends on the successful negotiations with land owners.

In the case of a public project, the project promoter may get the land either by common agreement with the land owners or through an expropriation process. In either case, both parties aim to reach fair and timely compensation for the land but the perception of each party on the meaning of this may prompt a conflicting situation. The former approach is more straightforward than the second, therefore some reduction on conflict intensity may be achieved if this option is invoked by one party while negotiating a common agreement with the other party. This strategy particularly applies to buildings or parcels of land that do not directly affect the home or the livelihood of people, in which case other aspects than money and time may prevail. Sometimes, only by finding an alternative home with equivalent location or alternative farming with similar conditions (such as access and water) contributes for decreasing conflict intensity with families affected. But obviously, this will also depend on the solvency of people concerned.

\section{Public in general}

Public in general may be affected by the project and because of that may be considered an external stakeholder. Any project has positive and negative externalities mostly coming about during the construction and the utilization stages.

Some of these externalities are environmental impacts and may be related to the construction stage, to the utilization stage or to both of them. In some countries, it is mandatory to develop an EIA (Environment Impact Assessment) for large projects like roads, bridges and shopping malls. The EIA often addresses the utilization stage of those projects and sometimes the construction phase as well if the site is expected to create significant impacts (in a dam project, for example). One of the steps of the EIA is the public consultation process, where an accurate identification of stakeholders and the presentation of their concerns and expectations should be considered.

Although in a smaller scale, the construction stage of any project may cause relevant environmental impacts, for example dust, mud, ruined accesses, long traffic deviations, noise, risk of injury while crossing the site, damages to private property, etc.

Externalities should always be considered before construction commences and preferably at the pre-design stage where all the negative and positive impacts of possible solutions should be addressed and compared, including the zero option (doing nothing). This is essential for avoiding conflicts. Additionally, there are cases where public participation adds significant value to the project. For example, in a public transportation project, different solutions may be proposed to the people affected by the project. Because of their knowledge about the project location, their suggestions may be advantageously considered and possibly adopted at the design phase if they prove technically feasible, therefore avoiding future conflicts.

Public in general includes real estate owners, nearby residents, local communities and so on, each of those may be viewed as an independent subcategory of stakeholders. Nearby residents are people living or working close to the project and expect receiving information about construction evolution, respect for their daily life and that everything on site is 
being done, to solve and minimize the problems. The difference for local communities is that these are organized, include small businesses and can be categorized (for instance, a specific neighbourhood). Normally, local communities are organized and have their own representatives to whom the construction project should be first explained and communication directed. If the local community is affected by the project, there will be the risk of potential conflicts, if that is not regarded in the project decision process.

\section{Local trade and industry}

Local trade and industry are usually considered independent stakeholders from the general public because they may be affected by different project externalities. Trade and industry are businesses of several kinds (small manufacturing activities, restaurants, shops, etc.) that may be positively or negatively affected by the project. For example, they may possibly benefit from a new infrastructure project (improved communications) or loose clients to a new shopping mall (reduced attractiveness).

Building up the project may have similar impacts. For example, local restaurants may possibly gain new clients (working on or visiting the site) or loose used to be clients (because of traffic deviation). In order to properly manage these potential conflicts, negotiated solutions with trade and industry representatives must be found, for instance through the betterment of local facilities or by compensating expected profit decrease.

\section{Environmentalists}

Like other Non Governmental Organizations, environmentalists have the power to influence project decisions, as their aim is to alert the public opinion to the negative project consequences to the environment. Conflicts can arise if the project management team neglects or detracts their views with poor structured arguments. For a project where the EIA is not compulsory but for which environmental impacts are claimed, it is adequate to conduct a consultation process to the active environmentalists and to negotiate alternative project solutions although not compromising the main objectives of the project.

\section{Local and national authorities}

These are very important stakeholders because they have the power to influence project decisions by issuing final approvals on the project. These stakeholders are ruled by civil servants and politicians (mayor, minister, secretary of state, directors, etc.), therefore project conformance with rules and regulations partially depends on their interpretation on those rules and regulations and on the directives they must comply with in order to sustain strategic political decisions.

Conflict avoidance with these stakeholders is decisive for the project success, and may be achieved by maintaining informal contacts with them in all stages of project development. This is particularly important during the design phase and the pre-construction phase of the project in order to anticipate their decisions.

\section{Media}

According to some authors, media may not actually be considered a stakeholder as they have no stake in the project. However, media can have a decisive power and capability of influencing other stakeholders in the project decision process. Furthermore, it is common that some stakeholders use the media for influencing other stakeholders' decisions on the project (for example, politicians or national authorities relevant to the project approval or rejection). Taking into account the power of media, conflicts should be avoided through the implementation of adequate communication. 


\section{Political organizations and interest groups}

Especially for large public projects, it is crucial that the main political parties converge on the project aims, the main technical solutions and the sources of funding. In recent years, interest groups have taken the lead in some projects but political organizations still hold significant power to influence decisions on projects holding regional and national relevance.

Interest groups are also called lobby groups and may act both locally and nationally as proponents or opponents to a project. Interest groups can be formed in many different ways and have different power to influence project decisions. Normally, they act in the pre-construction phase of the project, with the aim of conducting the process to fit their interests of location, dimension, accessibility or user facilities.

Conflicts arise when the decisions are opposite to the interests of the above stakeholders. They may then attempt to use their power and political influence, to discredit the decision and eventually change it according to their interests.

As for large private projects, the support from political parties and interest groups may avoid strategic opposition to the necessary approvals during the design and pre-construction phase. On the contrary, their opposition may lead to major difficulties for conducting the project, cause delays and possibly lead to the project abortion.

One particular way of reducing conflicts with these stakeholders is to carefully sustain the decisions with sound technical background, to present them truly and clearly and to personally interact with the relevant actors in order to better explain them.

\section{Social and professional organizations}

Trade unions are examples of social organizations that may have some influence on the project. They may act as supporters during the feasibility phase of the project, help during the design phase and influence political decisions during the pre-construction phase (trade associations, for example). But they may also act as project opponents during the construction stage if site impacts are significant or site conditions are not acceptable for workers (trade unions, for example).

Managing conflicts with these stakeholders during the design and pre-construction stages is similar to the described above for other similar organizations. Conflicts arising due to poor work conditions on site, low wages and excessive extra-working hours can be avoided or minimized if the project management team keeps regular meetings with worker representatives in order to understand their concerns and explain the decisions that affect workers' salary and safety conditions.

\subsection{Conflicts between internal stakeholders}

Unlike external stakeholders, internal stakeholders to construction projects are usually tied by mutual contract arrangements, whereby rights and duties of the parties are set, as well as the risks each party ought to bear and if these can be insured. Additionally, contracts usually establish the resolution procedures of conflicts possibly arising from their relationships.

\section{Project owner}

The owner is the most relevant project stakeholder and is mostly affected by the project success. Accordingly, the owner is expected to develop all the necessary efforts to avoid project conflicts or, at least, to minimize them to a controllable level, by using adequate conflict 
management techniques. The owner may also play the role of sponsor, promoter and client for the other project stakeholders.

Conflicts may start at the owner organization. Especially in public entities, some internal opposition to a particular project may arise, due to either resource dispute or conflicting approaches on investment priorities between different sectors. These conflicts should be adequately managed by using sound decision criteria, adequate diffusion of needs and expected benefits for end-users and previous alternative solutions under scrutiny.

\section{Costumers and end-users}

The ultimate reason to launch a construction project obviously depends on the needs of these stakeholders (either assigned or not, either directly or indirectly), thus evidencing their importance. For private investments (houses, offices, stores), needs are usually evaluated through market research techniques. The costumer is the end-user of the facility and who directly pays for it (either by purchase or rental in its multiple forms). For public projects, however, the enduser may not directly pay for the facility (as in public concessions) but indirectly through taxes. Accordingly, end-users' needs should be properly identified during the conception and the design phase, in order to avoid conflicts during construction, due to mistaking their expectations.

\section{Financiers and creditors}

Financing institutions need to ensure the return of investment and adequate profitability if the funds are private, and the achievement of the project goals of scope, time, cost and quality, if the funds are public. If project costs escalate, incomes may reduce or the project profitability may be at risk, therefore financiers may stop capital allocation or creditors may claim for the payment of debts, therefore endangering the project conclusion. This evidences their importance as project stakeholders. Adequately managing internal conflicts implicates accurate and permanent monitoring of the project's cash flow, as well as the use of risk analysis techniques in order to ensure alternative solutions if, for instance, the planned revenues are not achievable.

\section{Designers, suppliers, contractors and subcontractors}

This group of stakeholders contributes with products and services to the implementation of the project. Before construction begins, the designer is the most important stakeholder, while afterwards the contractor becomes the most relevant. Depending on the type of delivery, procurement process, distribution of risk chosen by the project owner and the type of contract arrangement (traditional, cost plus, construction management, etc.), conflicts may be more or less manageable and more or less contained.

Conflicts between the contractor and the client frequently arise from different site conditions, change orders, delays, suspension of works, defective contract documents, among others. Normally, conflict resolution procedures are disposed in contractual documents, and, depending on different legal systems, they ought to include direct negotiation, mediation, adjudication boards, dispute review boards, etc. The main measures to avoid conflicts must be implemented in the design and the pre-construction stages, as they are focused on improving the quality of contract documents and include, for instance, geotechnical baseline reports, constructability reviews and partnering approaches.

\section{Employees}

Employees of any stakeholder organization can obstacle the project success, if they are not sufficiently motivated by the project, or if they have any kind of conflict within their 
employer (salary, promotions, work conditions, etc). This type of conflicts often arise, through strikes, organized meetings or written claims to the board of directors, and should be tackled by the Human Resources Department of the organization concerned.

\section{Project management team}

The project management team is the instrument used by the project owner to achieve the project goals and objectives. In order to meet all the specifications and requirements established for the project, the team should hold sufficient empowerment and embrace all necessary competences. Conflicts frequently emerge from different views and perspectives on the assignment of responsibilities and emergent relationships. These should be properly established prior to the beginning of the project, through responsibility matrixes and adequate communication channels.

\subsection{Relationships between stakeholders}

Depending on the way they react to conflict situations the relationships among stakeholders identified above can be classified as unitary, pluralist, or coercive (Rijsberman, 1999):

- A unitary relationship refers to conflicts where a (probably small) number of stakeholders have similar values, and the parties to the conflict are likely to agree on objectives, but may still have conflicts of interest.

- In a pluralist situation, stakeholders do not agree or do not share each other's value systems, neither one of the stakeholders dominates, even though parties ought to reach compromises on objectives and values.

- A coercive relationship among stakeholders describes a situation in which parties do not share a common value system, but one of the stakeholders is powerful enough to make its own value system dominant (and coerce the other stakeholders to accept it).

The relationships established between stakeholders and the balance of power among parties is an important issue in every conflict. Actually, those relationships can range from a basic agreement on objectives, but conflicting interests, to situations where one of the stakeholders is powerful enough to coerce the other to acquiesce to them. For that reason, and, as will be seen further in this chapter, alternative resolution methods like mediation or arbitration are more effective when biased or unbalanced power is present because the most powerful party tries to force its reason.

\subsection{Conflict management}

International literature essentially deals with conflicts in construction under the following approaches:

- by analyzing conflicts between the client and the contractor (particularly under traditional contract arrangements), usually by adequately managing construction claims;

- by identifying possible conflicts with external stakeholders (this being an undesirable phenomenon to be reduced and ideally eliminated from the construction process) through understanding and mitigating their underlying causes. 
The efficacy of the preventive approach predominating in the construction industry has been challenged by those who consider conflict inevitability and view the problem in the way it is managed rather than in its existence. Therefore, the trend nowadays is developing efficient conflict management approaches, rather than minimizing possible conflict sources. Furthermore, conflicts may lead to the best possible solution to the problems under discussion and become an opportunity for organizational learning, creativity and fulfilment of organizational and individual potential (Hughes, 1994).

Actually, the goal of conflict management is not to avoid conflicts, but to develop the skills and methods to help conflicting people, groups or organizations in conflict, to express their differences and solve their problems in a collaborative and constructive way. Therefore, it is essential that conflicting stakeholders are fully involved in the resolution process as a way of developing effective methods for dealing with their differences. Moreover, disputes may result in litigation which instead of being fair and equitable, may not be the best solution for all conflicting parties. Avoiding this outbreak is one of the most decisive reasons for implementing conflict management techniques.

The classical approach for successful conflict management maximizes the integrative function of the two parties in conflict (the win-win approach) although it ignores the consequences of the solution for third parties affected by the dispute. However, the correct framework for conflict management should also take into account the maximization of outcomes for all the other stakeholders, through a utility function like (Wall and Callister, 1995):

$\operatorname{Max} Y=a+b_{1} x_{1}+b_{2} x_{2}=b_{3} x_{3}+\cdots \cdot+b_{n} x_{n}+b_{n+1} x_{1} x_{2}+b_{n+2} x_{1} x_{3}+\cdots$,

where

$\mathbf{x}_{\mathbf{1}}$ - utility to disputant 1

$\mathbf{x}_{2}$ - utility to disputant 2

$\mathbf{x}_{3}, \ldots \mathbf{x}_{\mathbf{n}}$ - utility to third parties affected by the dispute between 1 and 2 .

Additionally, adequate conflict management techniques should not just maximize all parties' outcomes, but also increment relationships between them, as a way for reducing future disputes (this assignment is represented by the term $b_{n+1} x_{1} x_{2}$ ) and to increase the joint utility represented by the above function.

The assessment of conflict between stakeholders in construction projects depends on four essential factors, the first three of them being endogenous to the conflict and the last exogenous (describing the surrounding context):

- the type/power, characterization and relationships of the stakeholders (internal, external, authority/public/contractor);

- the stage of the construction project cycle (pre-contractual, execution, exploration);

- the type, nature and stage of the conflict (behaviour, data, needs, values, latent, potential, processes, etc.);

- the legal and institutional context of the project (public, private, environmental, transportation, developmental, etc.).

The success of conflict management depends on the adequate interaction of the above factors through six basic steps (see Figure 17.5):

1. identification of the threat, type, stage and dimensions of conflict;

2. identification of underlying facts, perceptions, social needs and cause effect relationships; 


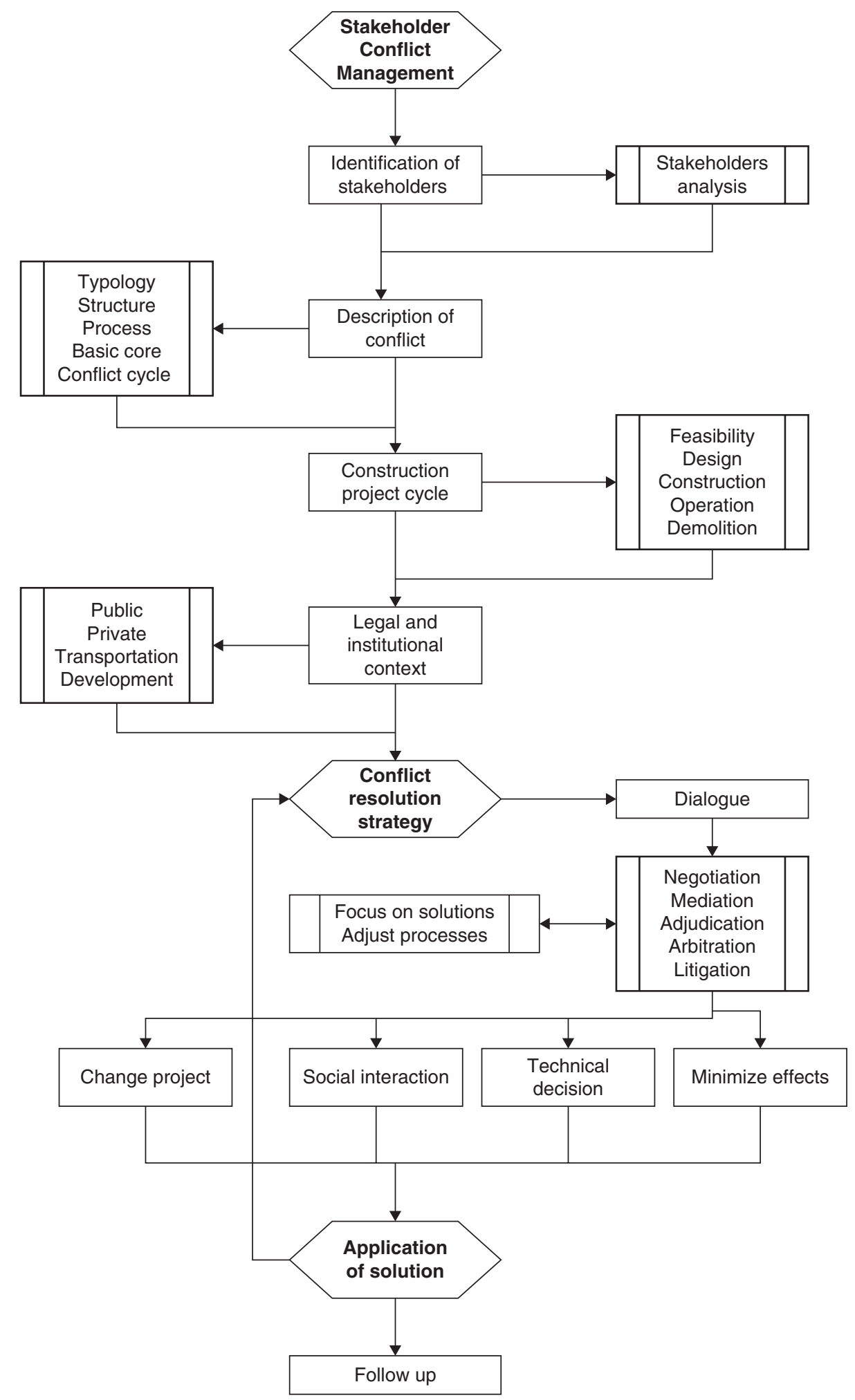

Figure 17.5 Conflict management phases. 
Table 17.2 Stakeholder analysis matrix

\begin{tabular}{|l|l|l|l|l|l|l|l|l|}
\hline \multirow{2}{*}{ Stakeholder } & \multicolumn{3}{|c|}{ Power analysis } & \multicolumn{2}{c|}{ Importance/interest } & \multicolumn{3}{c|}{ Conflict/impact } \\
\cline { 2 - 9 } & Source & Level & Cooperation & Importance & Interests & Affect & Way & Details \\
\hline $\begin{array}{l}\text { Nearby } \\
\text { resident }\end{array}$ & $\begin{array}{l}\text { Votes/ } \\
\text { meetings }\end{array}$ & Medium & Good & Medium & High & Directly & Positively & $\begin{array}{l}\text { Reduce } \\
\text { distance }\end{array}$ \\
$\begin{array}{l}\text { Commercial } \\
\text { owner }\end{array}$ & $\begin{array}{l}\text { Pressing } \\
\text { authorities }\end{array}$ & Low & Weak & Low & Low & Indirectly & Negatively & $\begin{array}{l}\text { Reducing } \\
\text { incomes }\end{array}$ \\
$\ldots .$. & $\ldots$ & $\ldots$ & $\ldots$ & $\ldots$ & $\ldots$ & $\ldots$ & $\ldots$ & $\ldots$ \\
\hline
\end{tabular}

3. identification of all stakeholders, their interests, powers, fears and needs;

4. involvement of all recognized parties in the management process;

5. identification of suitable conflict management resolution strategy and choice of guidelines;

6. application of chosen resolution strategy and guidelines;

7. measuring the success of conflict management.

One of the most important phases of this process is the stakeholder analysis. This is used to identify, assess the importance and anticipate the influence (either positive or negative), that each stakeholder will have on the project. The results of this analysis are used to develop strategies for supporting effective conflict management procedures, by minimizing possible conflicts and reducing obstacles to its successful implementation.

The stakeholder analysis may be done by using the example matrix of Table 17.2, where the cells are filled with quantitative indicators.

\subsection{Resolution of disputes between internal stakeholders}

Parties to a dispute must first decide whether to seek resolution to a conflict through a nonconsensual process, like litigation or arbitration, or through more collaborative means like direct negotiation or conflict prevention techniques.

Once the decision has been taken, the parties must choose which approach to employ, since there is no methodology that will be effective in all cases, and indeed more than one may be used. The circumstances, conflict assessment and therefore the obstacles to agreement vary from one case to another. Disputes may involve many parties or only a few; the problem may be more or less urgent; the emotional investment and the power of the stakeholders may vary; the public interest may or may not be at stake and the factors involved may be well understood or more uncertain. Gaining expertise in conflict management includes learning about the specific advantages and disadvantages of the various strategies, and assessing which one is best for addressing a particular conflict situation.

Conflict resolution techniques may be viewed as a set of approaches ranging from those in which all initiatives and authority remain within the parties in conflict to those in which there is a strong intervention from a third party. On the other hand, although considerable differences may exist from one approach to the other, they may also overlap. Moving from the least to the most directive, most approaches will involve some element of relationships (direct negotiation), procedural assistance, substantive assistance, advisory non-binding assistance (mediation) and binding assistance as well (arbitration). 
The use of conflict prevention does not imply that conflicts between parties will not prevail. Similarly, the use of third party aid like arbitration does not imply that it will be less effective than the personal efforts of arbitrator to get the parties to cooperate as much as possible. When neutral parties play, the results will depend on the qualities and experience of the person or persons chosen. This implies that the selection of a conflict resolution technique is not independent from the external party involved.

\subsubsection{Abandonment}

Dispute resolution generally assumes that some pathway will be followed towards a settlement or acceptable decision. However, during the process, one party may possibly decide to discontinue with the dispute. Although they may not be considered dispute resolution techniques, avoidance or abandonment by one party are possible dispute actions and are quite frequent in construction. Reasons for this are diverse, including low expectations on positive results, lack of funds to pursue, commercial reasons, lack of assertiveness or passivity.

Avoidance, on the other hand, is normally structured as a procedure. Generally speaking, the best way to avoid conflicts and disputes with stakeholders is to promote dialogue. This assumption is reflected on the processes for dispute resolution between internal stakeholders as can be seen below.

Although abandonment always derives from the voluntary or involuntary decision of one side, avoidance is often induced by the nature of construction stockholder's procurement relationships. More specifically, contract forms have been developed in several European countries as a means to avoiding disputes between parties involved in construction contracts (and as a pathfinder for dispute resolution, as well). In some cases, the role of avoiding conflicts is assigned to one stakeholder. An example of this is the certification process carried out by the contract administrator or the project manager in most contract arrangements: although being a client agent, he or she is expected to fairly assess the amounts payable to the contractor by balancing its possible optimistic demands with the potentially restrictive views of the owner.

\subsubsection{Negotiation}

Negotiation is possibly the most common and inexpensive form of dispute resolution in construction, whereby the control of the dispute process remains within the parties involved. In order to achieve a good negotiated settlement for a conflict, four characteristics should be met: fairness, efficiency, wisdom and stability.

With the implementation of these type of measures, conflict resolution probably drives from win-lose situations to win-gain solutions, where all participants try to find new ways to reach their goals, and, at the same time, meet the goals of the opponents. In this process, parties may act by their own as in direct negotiation or may introduce an advisor or a facilitator.

The graph of Figure 17.6 shows the five common conflict handling styles that may be found during stakeholders' negotiation, in relation to individual or mutual satisfaction (Thomas, 1992; Loosemore et al., 2000). Essentially, two main approaches may be identified in Figure 17.6: competitive and cooperative.

Competitive negotiation applies when the party using it is insensible (or, at least, partially insensitive) to the needs and wishes of the other party. In this case, the insensitive party will do anything to get concessions, irrespective of the costs implied to the other party. 


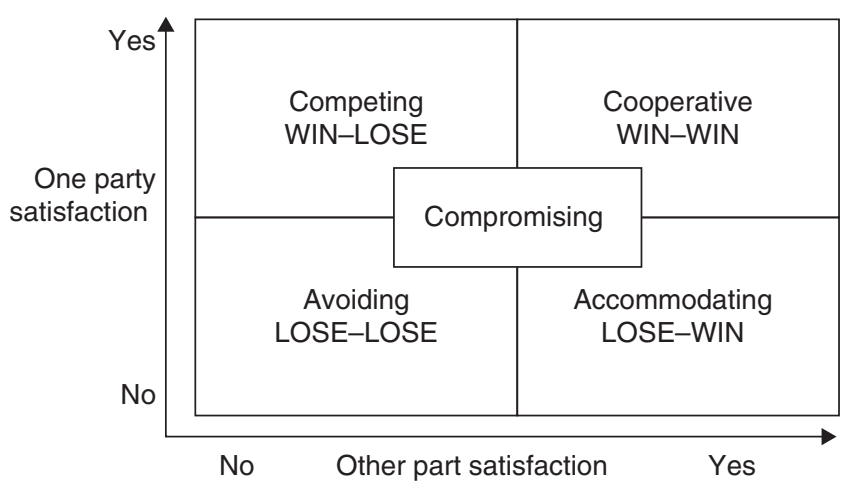

Figure 17.6 Conflict management styles.

(Source: Adapted from Thomas, 1992)

In order to achieve this, a variety of tactics may be employed that may be divided into the following three categories (Meltsner and Schrag, 1973):

- Positional tactics, aim at providing some form of advantage over the other party or at placing the other party at a psychological disadvantage. Examples of this are insisting that meetings take place at a place you may feel more comfortable than your opponent or trying to outnumber the number of participants of the other side for some functional reason.

- Initial tactics are used in order to try to achieve a favourable bargaining position from the start. Examples are to place your major demand first in the agenda or to start the negotiation with a higher demand than you really expect to obtain.

- A range of general tactics may also be used, the most common of which are: flattering, persuasion, promises or threats and irreversible decisions.

Cooperative negotiation is sometimes called win/win negotiation and as the name suggests pre-empts a very different approach from the competitive negotiation. According to Fisher and Ury (1991), there are five basic elements to this approach:

- Separate people from the problem: The opponent should be regarded not as someone you do not like and wishing to cause damage to you personally but as someone with whom you will have the chance of solving a problem through a mutual advantageous solution. Accordingly, negotiators should focus on the problem rather than in each others.

- Focus on interests not on positions: In an organization, interests are what really matters for problem solving not the victory of your position on the problem. Accordingly, negotiators should focus on the reasons for their demands.

- Generate options for mutual gains: Generally, it is better for you to find ways of increasing mutual benefits than to discuss with your opponent how to share it. Competitive negotiators will seek to obtain as much as possible during the negotiation process.

- Insist on using objective criteria: If criteria used during a negotiation process are validated by all parties involved, then chances will increase of getting a good agreement. Win/ win negotiators will adopt mutual recognized criteria to measure the outcome of their bargain.

- Consider the best alternative to a negotiated agreement: Negotiators should evaluate the consequences of not reaching an agreement through the negotiation process they are carrying. 
Clearly, the cooperative approach assumes conflict resolution through problem solving but some authors claim that this is not always possible. Arguably, ultimate hard negotiation tends to occur in every conflict-resolution process; this placing a competitive negotiator in a better position to win over a cooperative negotiator and not the contrary. However, Fisher and Ury (1991) contradict this view and state that it is possible to bring a competitive negotiator to a problem-solving negotiation by using the following five step approach:

1. Avoid attacking the other side and assume the position of an objective onlooker.

2. Listen and acknowledge the other side's point of view and agree whenever possible.

3. Direct the other's attention to the problem of meeting each side's interests.

4. Build on the other side's ideas in order to make it easy and convenient for him or her to agree.

5. Make it hard for the other to say no.

The negotiation process normally starts with an initial meeting where participants establish the game rules, get acquainted to each other's initial position and attitude, highlight main areas of agreement and disagreement and settle what type of records or data will be accepted.

According to the same authors, the negotiation process should be conducted as follows:

Establish commonly accepted facts.

Separate people from problems.

Base your position in principles, even if your opponent tries to make it personal.

Stress equality principles.

Ask questions instead of making statements.

Explore the principles of the other side.

Listen, rephrase and clarify your points.

Do not decide at once but give yourself time to think about the problem and to prepare a reply.

Expose your reasons before proposing.

Show your proposition as a fair solution.

Present your views on the consequences of reaching an agreement or otherwise.

Give the other side a chance of influencing the outcome of the negotiation process.

End up negotiation conciliatorily even if you do not completely feel it.

\subsubsection{Mediation and conciliation}

Mediation and conciliation is an ancient dispute resolution process that originated from China some 3000 years but its widespread use in construction is much more recent dating from the middle years of the last century. Mediation may be viewed as a negotiation process between disputing parties carried out with the help of a neutral and independent third party. It is essentially an informal process by which parties seek assistance from an independent consultant for solving their dispute. Therefore, the fundamental role of the mediator is to facilitate the decision making of the parties involved in the dispute. This is achieved by impartially 
advising and consulting them, helping the parties to understand their own and their opponent's position better, exploring alternative solutions and so forth. Accordingly, the mediator may act not just as an advisor but as a manager of the dispute process. Conciliation has been used quite interchangeably with mediation but tends to mean a more proactive attitude in some instances. In practice, the process of mediation or conciliation may be more facilitative or more evaluative depending on whether the consultant merely tries to aid communications between parties or if he or she comments on the subject matter and makes recommendations towards the outcome.

Three stages of the mediation process are usually identified in the literature, namely: premediation, mediation and post-mediation.

Pre-mediation corresponds to the preparation of the mediation process and includes the initial inquiry, procuring and contracting the mediator, preliminary preparations and first communications among parties (Brown and Marriot, 1993). The initial inquiry aims at agreeing on the process itself which may involve explanation and persuasion of the opponent parties. The procurement of the mediator is an important step towards mediation success because all parties must be convicted of the confidential, impartial, unprejudiced and legal nature of his or her performance. On the other hand, the mediation contract should establish the costs and the schedule of the process. Immediately after appointment, the mediator will become a party in the dispute process and as such should launch communications among parties and clarify their positions on the dispute. This may involve obtaining written summaries and supporting documents from each side for consideration.

Proper mediation involves, in the first place, meeting the parties and listening to their positions. Private meetings between the mediator and each party may be necessay, in order to build mutual confidence relationships, clarify some issues, identify needs and expectations and potential settlement options of each side, and so forth. These meetings are essentially consultative, not binding and are sometimes called caucus. In this process, the mediator may need to conduct several meetings with the parties, ask for advice from an expert or consultant, overcome impasse situations if they occur, etc. In the scope of this, he or she may perform more facilitative or more proactive of the ongoing negotiation. Finally, the mediator will record the agreements reached.

If agreements are met through the mediation process, then post-mediation is about their practical implementation. Otherwise, post-mediation will be the preparation for other forms of settling the dispute. However, it must be noted that successful mediation does not necessarily mean full agreement between sides nor the mediator should raise so high the expectations at the start. After mediation, the parties may have gained better insights into their dispute or may have limited the disputing issues thereby narrowing the field between them, and leading to a positive result.

In view of the above, the skills of the mediator and how efficiently he or she performs his or her functions play a decisive role in the mediation process. The role of the mediator has been described above and essentially involves managing the mediation process, collecting and analyzing information, facilitating communications, exploring possible solutions and promoting agreements between the parties. The skills required for a mediator to effectively achieve this are somewhat more difficult to state. Some of these skills derive from the nature of the functions and relate to the ability of being neutral and acting confidentially. Other skills are interpersonal mainly the ability to communicate and to achieve settlements. As for the latter, the mediator should base his or her decision/action on thorough investigation of each side's position and on inventing plausible solutions, while employing strategies like empathy, persuasion and distraction.

Some European countries have developed mediation and conciliation systems ranging from the facilitative end to the evaluative end of the spectrum, but in most cases the process 
is mainly informal. Informal mediation is essentially a flexible process conducted by a neutral agent engaged at a certain point of a dispute. This may take place by mutual agreement or may follow from the initiative of one side, after concluding that the negotiation process being carried needs help from a third party. A senior person recognized by the industry is often selected so that the chances of being accepted by all sides may increase. Initially, the mediator serves as a facilitator, informally discussing the dispute with the parties. In some cases, the facilitative role continues until both parties settlean agreement but in other cases, it ends up with some form of non-binding recommendation that the parties may possibly accept. Opposite to the informal mediation, following anofficial mediation system implies in some countries contracting mediators from a pre- assessed list.

\subsubsection{Expert assessment}

Expert assessment or determination is a process by which parties in a dispute commonly agree on asking a third party to decide a particular issue. Unlike mediation which is a nonbinding process, at least until some agreement may be reached, expert determination implies mutual acceptance of the expert decision. The use of this form of dispute resolution is very common in construction. Examples are real estate valuation, technical valuation in a number of circumstances and rent review. Actually, expert assessment often occurs in other forms of dispute resolution like in arbitration and in court litigation.

Unlike the mediator who need not be an expert (which in fact, may bias the mediator's view), the expert is by definition a specialist on the issue to deal with. Selecting and contracting the expert therefore assumes a paramount importance. Firstly, the subject of the expertise should be clearly and precisely expressed. Secondly, the costs and the schedule of the work to be performed should be established. Thirdly, the expert decision should be accepted to be the final and binding by all parties involved, unless one party further decides to challenge it through arbitration or litigation.

\subsubsection{Adjudication}

Adjudication may be defined as a process where a neutral third party gives a decision on some issue which is binding on the parties in dispute, unless or until revised in arbitration or litigation (Gould et al., 1999). Under traditional arbitration, the disputing parties must agree on the adjudicator who will thereafter act empowered by that agreement but unlike in mediation, the arbitrator's decision does not require the cooperation of the parties. The difference for expert determination is that the adjudicator may investigate the circumstances of the dispute and more freely interrelate with the parties than the expert tends to do.

Statutory adjudication was introduced in British construction following the recommendations in the Latham report (1994) and has no parallel in other European countries. Statutory adjudication is covered by the Housing Grants, Construction and Regeneration Act (Part II). Under this Act, a party to a construction contract is unilaterally given the right to refer to adjudication in order to solve a dispute arising from a contract. Therefore, unlike in traditional adjudication, no previous agreement between parties is required to start up a statutory adjudication procedure.

Section 108 of the Act sets out the minimum requirements for an adjudication procedure which may be summarized as follows:

- Notice: A party to a construction contract must have the right to give a notice at any time of its intention to refer a particular dispute to the adjudicator. 
- Appointment: A method of securing the appointment of an adjudicator and furnishing him or her with details of the dispute within 7 days of the notice is mandatory.

- Timescales: The adjudicator is then required to reach a decision within 28 days of this referral.

- Impartial action: The adjudicator is required to act impartially.

- Inquisitorial action: The adjudicator is required to take the initiative in ascertaining facts and the law.

- Binding nature: The adjudicator's decision is binding until the dispute is finally determined by legal procedures, by arbitration or by agreement.

- Immunity: The adjudicator cannot be held liable for anything done or omitted in the discharge of his or her function unless acting in bad faith.

In addition to this basic procedural framework, the Act further requires that all construction contracts comply with the provisions of the Scheme for Construction Contracts.

Following the publication of the Act, the standard forms of contract mainly used in Great Britain incorporated the adjudication process in different ways. The Joint Contracts Tribunal (JCT) standard form, mostly used for building, was amended with a set of adjudication procedures whereas the Institute of Civil Engineering (ICE) issued a stand-alone adjudication procedure to be used together with its standard form, largely disseminated in civil engineering contracts. This complies with Latham's (1994) recommendation that standard forms should embrace a system for adjudication.

There are no restrictions on who may possibly be appointed as an adjudicator either acting informally or under a statutory procedure. Many British construction bodies have established lists or panels of their own approved adjudicators but there are few restrictions on who can join the lists. An Academy of Construction Adjudicators has also been created.

\subsubsection{Arbitration}

In the last few years, construction industry has encouraged the use of international commerce practices by arbitration as an attempt to avoid costly and timely courtroom litigation procedures for solving disputes. This is a formal dispute resolution procedure subject to statutory controls, whereby disputes are solved by a private arbitrator selected by common agreement, or by a private tribunal, normally made up of three arbitrators, one appointed by each party and the third by common agreement. Arbitrators must have appropriate qualifications, minimum work experience and act impartially. During the arbitration process, arbitrators can call witnesses, require expert opinions and call the parties to testify, as well as other formal courtroom procedures.

Arbitration is voluntary, but once accepted by the disputing parties, the final decision is binding, unless a break of procedures, fraud or conflict of interest can be proved, in which case the decision may be revised by a court of law. Accordingly, the final decision may be enforced by the courts if necessary. Nonetheless, there are arbitration systems where the decision can be submitted to a court of appeal.

The advantages of arbitration when compared to litigation have been well acknowledged by the industry and include flexibility, economy, expedition, privacy, freedom of choice of arbitrators and finality (Gould et al., 1999). Besides being less costly and time consuming than the court of law, the arbitration tribunal is composed of recognized experts in the construction field, who are familiar with the industry practices, which may not be the case with common judges. Therefore, disputing parties feel that arbitrators can best understand their problems and are best prepared to reach an equitable solution for the dispute. However, some disadvantages have been recognized when more than two contenders are involved. 
Four stages of the arbitration process are usually identified in the literature:

- The arbitration agreement, whereby parties agree they will submit to arbitration present and future disputes.

- Selection of the arbitrator or arbitrators, by common agreement of the conflicting parties.

- The arbitration procedure, starting with the initiative of one of the parties after recognizing that a dispute has arisen.

- Award and enforcement which is final and binding on the parties, unless on the cases mentioned above.

There are ofcourse limits to the type of disputes that can be handled through arbitration and in some cases there are established limits to the maximum amount of money that can possibly be involved. Moreover, the arbitration process presents a set of variants:

- Documents only, by which the arbitration tribunal decides upon the documents submitted by the parties without hearings.

- Amiable or ex aequo et bono, if the arbitrator aims at arriving at a an equitable solution for the conflict.

- Last offer arbitration which is based on the offer of each party in monetary terms for a specific conflict.

Arbitration itself may have different names depending on the specific construction legal systems, like adjudication boards, dispute review boards, mini-trials, private judging, etc.

\subsubsection{Litigation}

If no agreement is achieved between conflicting parties to use any of the previous systems for resolving their disputes, then they can apply to the courts of law. Litigation is the current name for disputes dealt with in the courts of law.

The procedure followed by the courts starts with the claimant issuing a case and the claim particulars. Then the defendant is given the opportunity to admit the claim, defend from the claim particulars or merely acknowledge receipt of the claim form. The defendant may also decide to make a counterclaim. The legal system of each country follows a specific litigation track but it is not unusual that different tracks are adopted according to the nature of the claim and to the financial amount claimed.

The next step is the trail whereby the court of law will decide the merit of the case, in terms of legal evidence, sustained facts and quantum evaluation. However, very few proceedings result in trial and subsequent judgement in the European tradition, mainly because parties often reach an agreement just before the trial. In other occasions, the claimant may obtain judgement without trial because of any process flaw of the other side.

The complexity of some construction disputes often requires courts to contract experts for case assessment. Usually, a commission of three experts is appointed, one by each side and the third designated by the courts. The report of this commission is then added to the process but in most countries it is not binding. Once starting their functions, the experts must act neutral and professionally but their role has been criticized for supporting their client's position rather than providing an independent opinion. For this reason, many reports are not unanimous and do not give confidence to the court's decision. 


\subsubsection{Building bridges}

Despite the great variety of dispute resolution processes presented above, there is a trend in the literature for conflict prevention essentially focused on the anticipation of disputes from the construction stage to the design stage of project development. This has advantages of gaining time and benefiting from the dispute outcomes to enhance the project.

This can be done by improving the quality of contract documents as most construction disputes actually result from problems originating in the design or in the pre-construction phase of projects. Providing for independent design-quality review, mandatory insurance against errors and omissions and demanding for total quality management of architectural and engineering firms are some examples of good practice of dispute avoidance.

One common source of claims and disputes, representing a significant risk of cost and time overruns is the different site conditions encountered by contractors. In most cases this results from insufficient geotechnical subsurface studies, or from misunderstanding of site surveying reports. The concept of Geotechnical Baseline Report has been introduced to overcome this problem, whereby the designer states the ground conditions admitted for the design, on the basis of site investigation (if any) performed. Furthermore, the report anticipates the subsurface behaviour in respect to the most likely construction method to be used by contractor, as well the necessary information about slope stability, dewatering methods and strength of bedrock levels.

Another type of measure which can be implemented on the design and pre-construction phase of a project is the constructability reviews and the value engineering incentive clauses. Constructability can be defined as the optimum use of construction knowledge and experience in planning, design, procurement and field operations to achieve overall project objectives. Normally, constructability reviews are done in the last stage of design process, by the construction staff experienced in past projects and familiar with claims and disputes presented in those projects. Value engineering is the assurance that the constructed facility is adequate for its function at the lowest reasonable life-cycle cost, where the value index refers to the ratio of the worth of materials or methods required to provide the function, against their cost. This approach can be used either in the design phase, where the implementation can provide higher savings, or in the construction phase through an incentive clause in the contract, where the savings from value engineering studies are apportioned between client and contractor. Normally, this contract clause motivates the presentation of better cost-effective solutions, but still meeting the objectives of the project, once it guarantees rewards for discovering value engineering improvements.

Another bridge for dispute resolution comes from the concept of amicable settlement first introduced in a clause of the 1987 Fourth Edition to the FIDIC Red Book. Basically, the clause is a pre-requisite to arbitration and states that no notified arbitration may commence unless an attempt has first made by the parties to settle the dispute amicably. Other codes of practice throughout Europe, although not specifically referring to the amicable settlement of disputes, may recommend that other forms of dispute resolution may be attempted by conflicting parties prior to embarking on an arbitration procedure, for example negotiation and mediation. In the scope of these, the role of consultants and mediators is above all to facilitate the settlement, therefore bridging the gap between contenders.

Moreover, contract forms may encompass dispute avoidance techniques by endorsing the power to resolve differences between parties to a specific stakeholder, as in the certification example mentioned earlier on this section. Another example is partnering contracting which can be defined as the establishment of a working team among the parties, for mutually beneficial resolution of the ongoing difficulties and problems that typically arise on a construction project. The objective of this technique is to set up a climate of cooperation, communication, 
fair play and mutual confidence between client, contractor, designer and other stakeholders, which can start even before the bidding stage. This process consists of voluntary workshops, seminars and meetings that help the parties establishing working relationships in a non-adversarial atmosphere, where arising problems can be discussed and resolved, therefore avoiding the build up to formal claims.

Under the same logic, in an effort to prevent the escalation of a dispute between the owner and the contractor, an independent third party may be agreed for settling disagreements soon after they occur. This neutral exists either formally or informally in a set of European countries. In Britain, for example, this was named the Dispute Resolution Adviser after the work of Chartered Institute of Arbitrators.

Similar to this concept are the Dispute Resolution Board developed in the United States and the Dispute Review Boards in other countries. Essentially, they are boards of three people who evaluate the disputes as they arise during the project and make recommendations to the parties. The boards are constituted and agreed for each construction contract (each party selects one board member and agree on the third) at the commencement date. Like arbitrators, the members of the boards should be construction industry experts recognized by both parties, acting impartially and objectively, whose main assignment is to get information about project progress and observe construction problems as they occur, being able to encourage parties to deal with them promptly and realistically in cooperation with each other. Another example is the Dispute Adjudication Boards provided in the FIDIC General Conditions.

Multi-stage approaches for dispute resolution are also common. Accordingly, parties try the mediation approach in the first place and step to other more formal approaches if it fails, like arbitration. Currently, the mediator is later appointed as arbitrator, therefore benefiting from his or her previous knowledge on the dispute. A compulsory multi-stage approach may also be stated in the contract whereby, according to the financial amount claimed, complaints may be tackled through arbitration or must otherwise follow a litigation procedure.

Mini-trials and executive trials are a new trend. All the dispute resolution process takes place in a short period of time (say 1 or 2 days) and is conducted by an independent third party with recognized law expertise acting as a facilitator. The parties are represented by executives of the disputing parties holding decision power that have the opportunity of settling out their differences in a private look like courtroom.

\subsection{Resolution of disputes between external stakeholders}

Applicable procedures for dispute resolution involving external stakeholders are much less structured than above and the risk of dispute escalation to litigation is much higher. Generally speaking, dialoguing is the easiest path to conflict avoidance.

\subsubsection{Dialoguing}

Stakeholder dialogue is based on the principle that people affected by decisions ought to have an effective participation in the decision-making process. This should be done at an early stage when all the options for the construction project are still possible, and the opinions of participants can influence the outcome. This means the earlier stages of the design phase. 
The effectiveness of dialoguing increases as stakeholders are prepared to accept changing their views if adequately convicted. Moreover, dialoguing encourages people to step down from positional argument with win/lose outcomes and focus on cooperative and creative problem solving by working together in a consensual process, using the body of knowledge and ideas that each stakeholder brings up. Best practice includes the promotion of workshops, workgroups, seminars, study circles, open houses and so forth. Olander (2003) identifies the aims of these initiatives as follows:

- to provide stakeholders with all the relevant information about the construction facility or process;

- to justify why they are being involved;

- to explain why and how their input is useful and where it fits in the overall decision-making process;

- to clarify the extent to which it may influence the final decision of the project solution.

The outputs of the dialoguing process are often well informed and technically acceptable solutions acknowledged as the best possible options by the majority of the stakeholders. More importantly, the process tends to generate active support for the project and improved relationships within the community.

However, relations with external stakeholders must be carefully established. Depending on the significance of the construction project, the origin of the funds (public or private), the nature of the facility being developed and the type of stakeholders, there are different ways relations may be built with the aim to avoid possible conflicts. Table 17.3 depicts different ways of relating, and the expected level of influence in the project decision-making process.

Despite conflict avoidance efforts, conflict situations may possibly break out involving external stakeholders, due to:

- strong stakeholder interests (inflexible, unwilling to modify demands);

- lack of information or poor communication strategy;

- inter-personal conflicts;

- lack of consultation process.

The next sections deal with negotiation and an example of strategy for overcoming a specific conflicting situation.

\subsubsection{Negotiation}

Most of what has been said about negotiation between internal stakeholders is applicable with some adaptation to conflicts involving external stakeholders as well. Additionally, in most countries, this is the only possible approach to conflict settlement before litigation when external stakeholders are concerned.

The same two main approaches as before may be identified in negotiation: competitive and cooperative. The following lists a set of good practices and tactics that may help to maintain conflict situations under control, either for general interactions (Wall and Callister, 1995) or for construction industry specific interactions:

- Foresee issues: undertake conflict analysis and mapping

- Evaluate the extend of stakeholders' participation in the final solution (there are different cultural backgrounds) 
Table 17.3 Ways of relating to stakeholders

\begin{tabular}{|c|c|c|c|c|c|}
\hline & $\begin{array}{l}\text { Type of } \\
\text { relations }\end{array}$ & Description & $\begin{array}{l}\text { Stakeholders } \\
\text { influence in } \\
\text { decisions }\end{array}$ & Actions & When to use \\
\hline \multirow[t]{2}{*}{ Least } & $\begin{array}{l}\text { Giving } \\
\text { information }\end{array}$ & $\begin{array}{l}\text { Stakeholders are } \\
\text { informed about the } \\
\text { project }\end{array}$ & None & $\begin{array}{l}\text { - Press release, TV } \\
\text { - Newsletters }\end{array}$ & $\begin{array}{l}\text { Information not } \\
\text { controversial/trust }\end{array}$ \\
\hline & $\begin{array}{l}\text { Gathering } \\
\text { information }\end{array}$ & $\begin{array}{l}\text { Stakeholders } \\
\text { provide information } \\
\text { to help decisions, } \\
\text { but don't } \\
\text { participate }\end{array}$ & Very little & $\begin{array}{l}\text { - Questionnaires } \\
\text { - Interviews } \\
\text { - Surveys }\end{array}$ & $\begin{array}{l}\text { Reliance on the use } \\
\text { of information }\end{array}$ \\
\hline \multirow{3}{*}{ 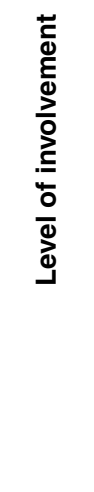 } & Consultation & $\begin{array}{l}\text { Stakeholders are } \\
\text { consulted but } \\
\text { don't participate in } \\
\text { decisions }\end{array}$ & Limited & $\begin{aligned} \text { - Written } \\
\text { comments } \\
\text { - Interactive } \\
\text { meetings }\end{aligned}$ & $\begin{array}{l}\text { Stakeholders trust } \\
\text { in decision-making } \\
\text { process }\end{array}$ \\
\hline & Participation & $\begin{array}{l}\text { Decision-making } \\
\text { process is shared } \\
\text { with some specific } \\
\text { stakeholders }\end{array}$ & $\begin{array}{l}\text { Can influence } \\
\text { specific } \\
\text { subject or } \\
\text { issue }\end{array}$ & $\begin{array}{l}\text { - Workshops } \\
\text { - Topic groups } \\
\text { - Round table } \\
\text { meetings }\end{array}$ & $\begin{array}{l}\text { Willingness and ability } \\
\text { to accept influence of } \\
\text { outcome }\end{array}$ \\
\hline & $\begin{array}{l}\text { Bounder } \\
\text { dialogue }\end{array}$ & $\begin{array}{l}\text { Decision is taken } \\
\text { together after } \\
\text { dialoguing within } \\
\text { some pre-set } \\
\text { conditions }\end{array}$ & $\begin{array}{l}\text { Stakeholders } \\
\text { fully involved } \\
\text { with some } \\
\text { pre-set } \\
\text { constrains }\end{array}$ & $\begin{array}{l}\text { - The above } \\
\text { processes in } \\
\text { a pre-planned } \\
\text { and coherent } \\
\text { way, eventually }\end{array}$ & $\begin{array}{l}\text { - All solutions are } \\
\text { possible, within pre- } \\
\text { fixed parameters }\end{array}$ \\
\hline Most & $\begin{array}{l}\text { Open } \\
\text { dialogue }\end{array}$ & $\begin{array}{l}\text { Decisions is taken } \\
\text { together }\end{array}$ & $\begin{array}{l}\text { Stakeholders } \\
\text { fully involved } \\
\text { in decisions }\end{array}$ & $\begin{array}{l}\text { facilitated by } \\
\text { mediators }\end{array}$ & $\begin{array}{l}\text { - Wider and complex } \\
\text { problems, with } \\
\text { open outcomes }\end{array}$ \\
\hline
\end{tabular}

Source: Adapted from Eurosite, 2003.

- Keep players involved and processes transparent and clear

- Maintain the stakeholders enthusiastic and capability in participation

- Ensure that institutions have legitimacy, are trustable and inspire confidence

- Assure that stakeholders are aware of conflict boundaries (rights, roles, responsibilities, legitimacy)

- Adopt appropriate leadership styles

- Structure organization to avoid conflict

- Address conflict causes, diagnoses and implement corrections

- Promote meetings (workshops, seminars)

- Negotiate, mediate, and arbitrate

- Enforce truth

- Expand group boundaries

- Guide communications between disputants

- Set up formalized appeal systems

- Act as decision makers

- Offer incentives

- Enforce cooperative problem-solving attitude between disputants

- Recognize women as stakeholders and peacemakers

- Address implications for youth and children 
- Conduct relevant stakeholder analysis and conflict perceptions

- Build and maintain effective partnerships

- Recognize the primacy of local people

- Widen and deepen dialogue

- Recognize the potential and the limits of external influence

- Be transparent and communicate intentions

- Act in timely flexible ways and think long term

- Respect cultural diversity

- Recognize and act only so far as legitimacy allows and remains impartial

- Be accountable

- Enable institutional learning

- Use creative, incentive-driven approaches for construction engagement

- Act on lessons about the need for coordinated, coherent action and policy

On the other hand, according to Susskind and Field (1996), collaborative negotiation should follow the following six main principles for consensus building with external stakeholders:

1. acknowledge the concerns of the other side;

2. encourage joint fact finding;

3. offer contingent commitments to minimize impacts if they occur, promising to compensate knowable but unintended impacts;

4. accept responsibility, admit mistakes and share power;

5. act in a trustworthy fashion all the times;

6. focus on building long-term relationships.

\subsubsection{Not in my backyard}

One of the most common conflicts within external stakeholders is related to the location of new public facilities that local communities and residents do not want close to their homes. This is called the NIMBY (not in my backyard) syndrome. The symptoms of the syndrome are group actions, sometimes vigorous, by local communities to stop the implementation of the controversial project affecting their livings or the environment (industrial facilities, dams, waste treatment and so on). The question is how to solve this conflict, when even though the proposed construction meets all economic, legal and environmental requirements, is still not accepted by the public. Table 17.4 summarizes a set of proposed guidelines to help solve this conflict (Kunreuther and Susskind, 1991 cited in Olander, 2003).

\subsection{Conclusions}

Conflict is a complex behavioural process existing in all relations between individuals, groups of individuals and organizations. Conflict management is an important management function in the construction activity and should deserve considerable attention from all construction stakeholders. This is because construction projects involve a great diversity of people and organizations, experiencing a variety of situations throughout the project life cycle being tackled in the scope of different and possibly antagonistic interests of stakeholders.

Conflicts do not always have negative consequences but may lead to improvement in construction performance. Moreover, some stakeholders may benefit from conflicts and view them as opportunities for innovation. 
Table 17.4 Guidelines to help solve the NIMBY syndrome

\begin{tabular}{|c|c|}
\hline Action & Explanation \\
\hline $\begin{array}{l}\text { Institute a broad-based } \\
\text { participatory process }\end{array}$ & $\begin{array}{l}\text { Representatives of all affected groups should be invited to participate and assist } \\
\text { each stage of the decision process. All those affected should have a chance } \\
\text { to review the criteria for site selection. Groups with different points-of-view } \\
\text { should have a chance to criticize the recommendation of facility proponents } \\
\text { and the analyses upon which their proposals are based. A joint fact-finding } \\
\text { process should be used so that all stakeholders can play a role in specifying } \\
\text { the information about risks, costs and benefits that they need in order to make } \\
\text { informed decisions. }\end{array}$ \\
\hline $\begin{array}{l}\text { Achieve agreement } \\
\text { that the status quo is } \\
\text { unacceptable }\end{array}$ & $\begin{array}{l}\text { The sitting process must begin with an agreement that the facility is needed. The } \\
\text { relevant stakeholders need to understand the consequences of doing nothing. }\end{array}$ \\
\hline Seek consensus & $\begin{array}{l}\text { A serious attempt should be made to involve all the relevant stakeholders to } \\
\text { address their values: concerns, potential needs and wants. Differences can be } \\
\text { addressed by searching for new ways of framing questions or different ways of } \\
\text { packaging trade-offs. }\end{array}$ \\
\hline Work to develop trust & $\begin{array}{l}\text { Lack of trust is perhaps the most important barrier to reaching consensus. Those } \\
\text { attempting to site a facility must recognize potential sources of mistrust, including } \\
\text { lack of support for the project, previous negative experiences and suspicions } \\
\text { towards the government and other institutions. One way to establish trust is to } \\
\text { admit past mistakes and avoid exaggerated claims and promises that cannot be } \\
\text { fulfilled. }\end{array}$ \\
\hline $\begin{array}{l}\text { Choose the solution } \\
\text { that best addresses } \\
\text { the problem }\end{array}$ & $\begin{array}{l}\text { Problems must be addressed with a design and solution of the facility that } \\
\text { stakeholders can agree is appropriate. A comprehensive list of alternative } \\
\text { approaches and their long- and short-term implication, including the option of } \\
\text { taking no action, should be made public in non-technical language. The choice } \\
\text { of alternatives and technology should be based on input from the residents of } \\
\text { the community who may well know more about the problem 'on the ground' than } \\
\text { many experts. }\end{array}$ \\
\hline $\begin{array}{l}\text { Guarantee that } \\
\text { stringent safety } \\
\text { standards will be met }\end{array}$ & $\begin{array}{l}\text { No community should be asked to compromise its basic health or safety so } \\
\text { that a facility can be built. Preventive measures for reducing the hazard should } \\
\text { be encouraged and the proposed facility must meet all health, safety and } \\
\text { environmental standards, Interested parties should also have an opportunity } \\
\text { to specify any additional standards that could be met through mitigation, such } \\
\text { as changes in the design of the facility, substitute technologies, operational } \\
\text { modifications and training of operators. Monitoring and control procedures } \\
\text { involving the host community are important in minimizing risks and maintaining } \\
\text { standards. }\end{array}$ \\
\hline $\begin{array}{l}\text { Fully address all } \\
\text { negative aspects of } \\
\text { the facility }\end{array}$ & $\begin{array}{l}\text { When impacts cannot be prevented or mitigated to the satisfaction of the affected } \\
\text { parties, various forms of compensation, specified by the stakeholders involved, } \\
\text { can be negotiated. These agreements may include property value guarantees, } \\
\text { creation of equivalent habitats when loss is unavoidable, and the offer of service } \\
\text { when impact occurs. }\end{array}$ \\
\hline $\begin{array}{l}\text { Make the host } \\
\text { community better off }\end{array}$ & $\begin{array}{l}\text { The applicant should put a package of benefits together so that the host } \\
\text { community feels that it is better off with the facility than without it. }\end{array}$ \\
\hline $\begin{array}{l}\text { Use contingent } \\
\text { agreements }\end{array}$ & $\begin{array}{l}\text { Some concerns about the management of facilities can be resolved by specifying } \\
\text { contingent agreements that spell out what will be done in case of accidents, } \\
\text { interruption of services, changes in standards or the emergence of new scientific } \\
\text { information about risks and impacts, and provide means of guaranteeing that } \\
\text { contingent promises will be met at no cost to those likely to be adversely affected. }\end{array}$ \\
\hline
\end{tabular}




\begin{tabular}{|c|c|}
\hline Action & Explanation \\
\hline $\begin{array}{l}\text { Seek acceptable sites } \\
\text { through a volunteer } \\
\text { process }\end{array}$ & $\begin{array}{l}\text { Encourage communities to volunteer sites indicating that it is not an irreversible } \\
\text { commitment and that there are potential benefit packages that come with the } \\
\text { facility. }\end{array}$ \\
\hline $\begin{array}{l}\text { Consider a competitive } \\
\text { sitting process }\end{array}$ & $\begin{array}{l}\text { Assuming that multiple, acceptable volunteer sites are found, the sponsors of the } \\
\text { facility should consider a competitive process of site selection. }\end{array}$ \\
\hline $\begin{array}{l}\text { Work for geographic } \\
\text { fairness }\end{array}$ & $\begin{array}{l}\text { It is inappropriate to locate too many noxious facilities in a single locale even if a } \\
\text { community is willing to accept them. }\end{array}$ \\
\hline Set realistic timetables & $\begin{array}{l}\text { It is appropriate and helpful to set and enforce realistic deadlines. However, } \\
\text { a good process allows all parties adequate time to consider the full range } \\
\text { of options and weigh technical evidence as it is gathered. Opponents have } \\
\text { administrative and legal means of slowing, even halting, siting processes that } \\
\text { they feel have excluded them. It may be necessary to 'go slowly in order to go } \\
\text { fast'. }\end{array}$ \\
\hline $\begin{array}{l}\text { Keep multiple options } \\
\text { open at all times }\end{array}$ & $\begin{array}{l}\text { It is never a good idea to have only one possible site even at the final stage of the } \\
\text { process. Negotiations regarding possible incentive packages are more likely to } \\
\text { produce reasonable results if a facility sponsor does not feel 'held hostage' by the } \\
\text { only possible site. }\end{array}$ \\
\hline
\end{tabular}

Accurate conflict classification is the first step towards a timely and proper resolution of disputes. Accordingly, conflicts in construction have been categorized in various ways, namely by type, typology, level, object, stage in the project life cycle and underlying cause. The classification of construction stakeholders in the conflict context is also important for conflict analysis. These are named internal if they have direct participation in the project and external otherwise. Moreover, according to their interest, willingness and power to act, stakeholder groups may also be categorized in key players, keep-informed, keep-satisfied and minimal effort groups. Following the classification of construction stakeholders, several conflicts arising between them have been indicated, and corrective actions for conflict avoidance have been approached.

Recent trends in construction conflict analysis points up to conflict managing approaches rather than conflict avoidance techniques because it has been widely recognized that conflicts may lead to better and innovative solutions. In view of this, factors influencing the success of conflict management have been identified, and the phases towards adequate conflict resolution have been surveyed.

Additionally, different conflict resolution techniques have been analyzed, applicable either to internal or external stakeholders. The former include the opposite approaches of non-consensual processes like arbitration and litigation, whereas the latter include the more collaborative ones, like mediation and direct negotiation between parties. It has also been concluded that dialoguing and negotiating during the decision-making process is the best way to avoid future uncontrolled conflicts.

\section{References}

Brown, H. and Marriot, A. (1993) ADR Principles and Practice. London: Sweet and Maxwell.

Eurosite (2003) 73rd Eurosite Workshop, Natura 2000 - Conflict management and Resolution. Park Interrégional du Marais Poitevin, France, 2-5 April de 2003. Available at http://www.eurositenature.org/IMG/pdf/73_conflict_pt01.pdf (Accessed 17 November 2007). 
Fisher, R. and Ury, W. (1991) Getting to 'Yes': Negotiating an Agreement without Giving In (2nd edn). London: Century Business.

Gordon, J.R. (1996) Organizational Behaviour: A Diagnostic Approach (5th edn). Englewood Cliffs, NJ: Prentice-Hall.

Gould, N., Capper, P., Dixon, G. and Cohen, M. (1999) Dispute Resolution in the Construction Industry. London: Thomas Telford, Limited.

Groton, J.P. (1997) Alternative dispute resolution in the construction industry. Dispute Resolution Journal, 52(3):49-57.

Hughes, W. (1994) Improving the relationship between construction law and construction management. In: Fenn, P. (ed) Proceedings of TG15 Conference on Construction Conflict: Management and Resolution. Lexington, USA: CIB Publication No.171, 16-19 October 1994.

Johnson, G. and Scholes, K. (1999) Exploring Corporate Strategy: Text and Cases (5th edn). London: Prentice Hall Europe.

Kunreuther H. and Susskind, L. (1991) The facility sitting credo - Guidelines for an effective facility sitting process. EIA Review, University of Pennsylvania: Philadelphia.

Latham, M. (1994) Constructing the Team. London: HMSO.

Loosemore, M., Nguyen, B. and Denis, N. (2000) An investigation into the merits of encouraging conflict in the construction industry. Construction Management and Economics, 18(4):447-456.

Meltsner, M. and Schrag, P. (1973) Negotiating tactics for legal services lawyers. Clearing House Review, 7:259-263.

Moore, C. (1986) The Mediation Process, Practical Strategies for Resolving Conflict. San Francisco, CA: Jossey-Bass.

Olander, S. (2003) External Stakeholder Management in the Construction Process, Licentiate dissertation, Department of Building and Architecture, Lund Institute of Technology, Lund, Sweden.

Rijsberman, F. (ed.) (1999) Conflict management and consensus building for integrated coastal management in Latin America and the Caribbean. Resource Analysis Report for Inter-American Development Bank. Delft, Nederland. Available at http://idbdocs.iadb.org/wsdocs/getdocument.aspx? docnum $=359595$ (Accessed 9 December 2007).

Susskind, L. and Field, P. (1996) Dealing with an Angry Public: The Mutual Gains Approach to Resolving Disputes. New York: The Free Press.

Thomas, K. (1992) Conflict and negotiation processes in organizations. In: Dunnette, M. and Hough, L. (eds) Handbook of Industrial and Organizational Psychology. Palo Alto, CA: DaviesBlack® Publishing, pp. 651-717.

Wall Jr., J. and Callister, R.R. (1995) Conflicts and its management. Journal of Management, 21(3):515-558. 